\title{
STUDY OF THE ANTIFUNGAL POTENTIAL OF (R)-(+)-CITRONELLAL AND ITS ASSOCIATION WITH THERAPEUTIC AGENTS USED IN THE TREATMENT OF VULVOVAGINAL CANDIDIASIS
}

\author{
ESTUDO DO POTENCIAL ANTIFÚNGICO DO (R)-(+)-CITRONELAL E SUA \\ ASSOCIAÇÃO COM AGENTES TERAPÊUTICOS UTILIZADOS NO TRATAMENTO \\ DA CANDIDÍASE VULVOVAGINAL
}

\author{
Cássio Ilan Soares Medeiros ${ }^{1 *}$; Daniele de Figueredo Silva ${ }^{1}$; Ana Luíza Alves de Lima Pérez ${ }^{2}$; \\ Geraldo Gonçalves de Almeida Filho ${ }^{3}$; Abrahão Alves de Oliveira Filho ${ }^{1}$; Edeltrudes de Oliveira \\ Lima $^{1}$ \\ 1. Mycology Laboratory, Department of Pharmaceutical Sciences, Federal University of Paraíba, João Pessoa, Paraíba, Brazil; 2. \\ Department of Odontological Sciences, Federal University of Paraíba, João Pessoa, Paraíba, Brazil; 3. Department of Molecular \\ Biology, Federal University of Paraíba, João Pessoa, Paraíba, Brazil. cassioism@ hotmail.com
}

\begin{abstract}
Vulvovaginal candidiasis (VVC) is a common fungal infection that affects healthy women of all ages. At least $75 \%$ of women will develop one or more infections once during their lifetime, with 6 to $9 \%$ of those individuals developing recurrent infections. In view of this context, this study sought to evaluate the antifungal potential of the isolated $(R)-(+)$-citronellal $[(R)-(+)-C T]$ and associated to therapeutic agents of clinical importance. The enantiomer was solubilized in tween 80 and dimethylsulfoxide (DMSO). Posteriorly diluted in sterile distilled water up to the concentration of $2048 \mu \mathrm{g} / \mathrm{mL}$. The minimum inhibitory concentration (MIC) of the product was determined by microdilution in RPMI-1640 obtaining dilutions of $1024-4 \mu \mathrm{g} / \mathrm{mL}$. The minimum fungicidal concentration (MFC) was determined by the Sabouraud dextrose agar (SDA) depletion technique from aliquots of $1 \mu \mathrm{L}$ of the MIC, MIC $\times 2$ and MIC $\times 4$. The MIC and the MFC values of $(R)-(+)-C T$ for $90 \%$ of the $C$. albicans strains were 16 and $32 \mu \mathrm{g} / \mathrm{mL}$ respectively. In the susceptibility test, $C$. albicans presented a high resistance to fluconazole and to itraconazole, 12 $(92.30 \%)$ of the strains. However, for ketoconazole and miconazole the resistance was of $4(30.76 \%)$ and $3(23.07 \%)$ of the strains respectively. In the combination testing of the $(R)-(+)$-CT with ketoconazole and miconazole, the resistance was completely reverted. For fluconazole and itraconazole, the resistance was reverted in $9(75 \%)$ and $7(58.33 \%)$ of the strains respectively. The $(R)-(+)$-CT presented fungicide activity with MFC of MIC $\times 2$. When in combination with ketoconazole, fluconazole, itraconazole and miconazole increased the inhibition zones of these antifungal drugs, reducing the resistance against $C$. albicans.
\end{abstract}

KEYWORDS: Monoterpenoid, Anti-C. albicans. Antifungal agents. Secondary metabolites. Citronellal.

\section{INTRODUCTION}

Vulvovaginal candidiasis (VVC) affects $75 \%$ of all women at least once during their lifetime, occurring more frequently during fertile age (ADESIJI et al., 2011, GANDHI et al., 2015). Another smaller group of women (6-9\%) experience the recurrence of this disease, called recurrent vulvovaginal candidiasis (RVVC) and defined as presenting at least 3 symptomatic episodes during the 12 previous months even though some researchers demand still, an additional episode (FOXMAN et al., 2013, JACK, SOBEL, 2016). Although various species of Candida have been involved in VVC and RVVC, Candida albicans is the predominant etiological agent, causing $85-95 \%$ of these infections (HONG et al., 2014, BEHZADI et al., 2015).

VVC can be manifested as a simple form, as sporadic cases of light infection caused by $C$. albicans. However, complex or complicated cases are caused by other species of the genus Candida, and severe infections, VVC during pregnancy and associated to other medical conditions, such as immunosuppression or diabetes (LI et al., 2014). However, it is difficult to assess the exact incidence of $\mathrm{VVC}$, due to the high rate of indiscriminate use of medicines. Furthermore, the diagnosis is frequently and entirely based on signs and symptoms without any diagnostic tests to confirm, and the treatment depends on whether the infection is complex or simple (BEHZADI et al., 2015, DOVNIK et al., 2015).

A variety of antifungal agents have been widely used to treat these infections. The azoles including the ketoconazole, fluconazole, itraconozole and miconazole have been used in a variety of therapeutic schemes for the treatment of VVC and RVVC (SEKHAVAT et al., 2011). However, due to the dynamics of antimicrobial resistance, which involves a complex association of multiple factors inherent to both the host and to the 
fungus itself, therapeutic failure has been significant (ESPINEL-INGROFF, 2008). Particularly, the azoles, the most common antifungal medication used in this disease, have been presenting an unfavorable picture (PFALLER, 2012).

The essential oils, a large group of secondary metabolites of plants involved in the defense processes and synthesized in response to microbes and plague attacks by herbivore insects, display excellent antimicrobial, insecticide, as well as anticancer activity (PICHERSKY, GERSHENZON, 2002). The terpenoids are condensation products of isoprene, containing 5 carbon atoms in its structure. Are important components of essential oils with vast biological activity (SAMY, GOPALAKRISHNAKONE, 2008, LORENZI et al., 2009). The anti-Candida activity of essential oils extracted from plants has been reported in several scientific papers over the last years, and consequently the essential oils, as well as some of their phytoconstituents, are used topically in the form of creams, gels and pessaries for the treatment of microbial infections (MONDELLO et al., 2006).

Furthermore, there is a growing interest in the use of combination therapy in order to avoid the collateral effects associated with high doses or longterm usage of conventional drugs (WAGNER, 2006). It includes the use of combinations of synthetic substances, as well as natural products, together with conventional medicines against several infectious diseases, such as candidiasis. Some essential oils and phytoconstituents are reported to synergically improve the activity of antibiotics such as amphotericin B, ketoconazole and fluconazole (ROSATO et al., 2008, HEMAISWARYA et al., 2008, WAGNER, ULRICH-MERZENICH, 2009).
The phytoconstituent $(R)-(+)-\mathrm{CT}$, belonging to the group of the monoterpenoids, is one of the major substances of essential oils of aromatic plants, such as the ones of the genus Cymbopogon and Eucalyptus (AVOSEH et al., 2015, BATUBARA et al., 2015). The citronellal is isolated as a nonracemic mixture of the $R$ and $S$ enantiomers, and has shown to have several biological activities, among them, antimicrobial, antioxidant, herbicide, insecticide and repellent action (SCHERER et al., 2009, QUINTANS-JÚNIOR et al., 2011, BRITO et al., 2012, TOMAZ et al., 2014). In this context, it was aimed to assess the antifungal potential of the isolated $(R)-(+)-\mathrm{CT}$, and associated to therapeutic agents of clinical importance frequently used in the treatment of the vulvovaginal candidiasis.

\section{MATERIAL AND METHODS}

\section{Phytoconstituent, antifungal standards and substances}

The following substances used in this work were obtained commercially: enantiomer $(R)-(+)$-CT [(3R)-3.7-dimethyloct-6-enal] (Figure 1), (Purity > 90\%), dimethylsulfoxide (DMSO) and tween 80 (0.02\%) (all from Sigma-Aldrich, São Paulo, SP, Brazil). The tween 80 and the DMSO were solubilized in a proportion that did not exceed $0.5 \%$ in the test, and was posteriorly diluted in sterile distilled water in order to reach the initial concentration of $2048 \mu \mathrm{g} / \mathrm{mL}$ (HOOD et al., 2003, BRUNI et al., 2004; NASCIMENTO et al., 2007; PEREIRA et al., 2014). Furthermore, ketoconazole, fluconazole, itraconazole and miconazole were respectively, purchased from Control Center and Products for Diagnosis (CECON) Ltd. (São Paulo, SP, Brazil).

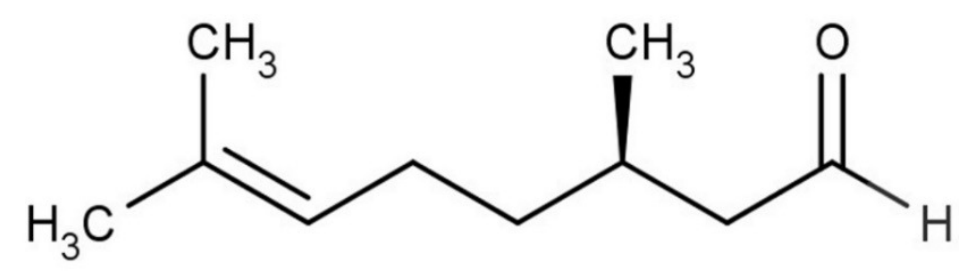

Figure 1. Struture of Citronellal $((R)-3,7$ - dimethyloct-6-enal)

\section{Culture media}

To test the biological activity of the products, Sabouraud dextrose broth (SDB) and Sabouraud dextrose agar (SDA) were purchased from Difco Laboratories (Detroit, MI, USA). Furthermore, RPMI-1640-L-glutamine (without sodium bicarbonate) (Sigma-Aldrich, São Paulo, SP,
Brazil) culture media were used. They were prepared and used according to the manufacturers' instructions.

\section{Fungal strains}

The assays were performed with 13 strains of C. albicans: LM 852, LM 157, LM 152, LM 240, 
LM 0202, LM 246, LM 228, LM 227, LM 319, LM 16 , and LM 15 (isolated from vaginal), and two standard C. albicans strains: ATCC 76485 and ATCC 76645. All strains belong to the collection of the Mycology Laboratory, Department of Pharmaceutical Sciences, Federal University of Paraíba (LM, DCF, UFPB). These strains were maintained in SDA at $35 \pm 2{ }^{\circ} \mathrm{C}$ and $4{ }^{\circ} \mathrm{C}$ until used in tests.

\section{Inoculum}

The suspensions were prepared from recent C. albicans cultures, plated on SDA, and incubated at $35 \pm 2{ }^{\circ} \mathrm{C}$ for $24-48 \mathrm{~h}$. After incubation, was transferred roughly 4-5 yeast colonies (with a sterile loop) to test tubes containing $5.0 \mathrm{~mL}$ of sterile saline $(\mathrm{NaCl} 0.85 \%)$. The resulting suspensions were stirred for 15 seconds with the aid of a Vortex apparatus (Fanem Ltd., Guarulhos, SP, Brazil). The turbidity of the final inoculum was standardized using a barium sulfate suspension (tube 0.5 on the McFarland scale). The final concentration obtained was about $1-5 \times 10^{5}$ colony forming units per milliliter (CFU/mL) (KONEMAN et al., 2008; OSTROSKY et al., 2008).

\section{Determination of minimum inhibitory concentration (MIC) and minimum fungicidal concentration (MFC)}

The determination of the products' MIC on the thirteen strains used in the biological assays was determined by the broth microdilution method (CLEELAND, SQUIRES, 1991, HADACEK, GREGER, 2000, NCCLS/CLSI, 2002). One hundred microliters $(100 \mu \mathrm{L})$ of liquid medium RPMI-1640 was transferred into the wells of a 96well microdilution plate with a "U" shaped bottom (Alamar, Diadema, SP, Brazil). Then, $100 \mu \mathrm{L}$ of $(R)$ $(+)-C T$ emulsion was inoculated in the first horizontal row of the plate wells. Doubled serial dilutions, where a $100 \mu \mathrm{L}$ aliquot removed from the most concentrated well went to the next well, yielded concentrations of $1024-4 \mu \mathrm{g} / \mathrm{mL}$. Finally, $10 \mu \mathrm{L}$ of $C$. albicans inoculum suspension was added to each well of the plate, where each column represented a yeast strain. In parallel, controls were made for yeast viability and for susceptibility with the standard antifungal nystatin $(100 \mathrm{IU} / \mathrm{mL})$. The plates were incubated at $35 \pm 2^{\circ} \mathrm{C}$ for $24-48 \mathrm{~h}$. After the appropriate incubation time, the presence (or absence) of growth was observed visually. The formation of cell clusters or "buttons" in the plate wells was considered. The MIC was defined as the lowest $(R)-(+)-\mathrm{CT}$ concentration that produced visible inhibition of yeast growth.
The antimicrobial activity of the products was interpreted (considered active or not), according to the criteria proposed by Morales et al., 2008: strong/good activity (MIC: $<100 \mu \mathrm{g} / \mathrm{mL}$ ); moderate activity (MIC: $100-500 \mu \mathrm{g} / \mathrm{mL}$ ); weak activity (MIC: $500-1000 \mu \mathrm{g} / \mathrm{mL}$ ); and inactive product $/$ no antimicrobial effect (MIC: $>1000 \mu \mathrm{g} / \mathrm{mL}$ ).

To determine the MFC, we subcultured 1 $\mu \mathrm{L}$ aliquots of MIC, MIC $\times 2$ and MIC $\times 4$ of the product, nystatin $(100 \mathrm{IU} / \mathrm{mL})$, and the control yeast growth onto Petri dishes containing SDA. After 2448 hours of incubation at $35 \pm 2^{\circ} \mathrm{C}$, a reading was made to evaluate the MFC, as based on the growth of the controls. The MFC was defined as the lowest product concentration that inhibited growth of the yeast or permitted less than three CFUs to occur, resulting thus in $99.9 \%$ fungicidal activity (ERNST et al., 1996, ESPINEL-INGROFF, 2002).

Biological activity assays were performed in duplicate, and the results were expressed as the arithmetic mean of the MIC and MFC.

\section{Susceptibility assays}

The fungal susceptibility test was carried out based on the disk-diffusion method in solid mean (BAUER, et al., 1966; KONEMAN et al., 1993; HADACEK, GREGER, 2000). In this test, the following antifungal medications were used: ketoconazole $(50 \mu \mathrm{g})$, fluconazole $(25 \mu \mathrm{g})$, itraconozole $(10 \mu \mathrm{g})$ and miconazole $(50 \mu \mathrm{g})$. The interpretation of the results was carried out using the sensitive or resistant criteria recommended by the (CECON) Ltd. (São Paulo, SP, Brazil) and the CLSI, 2009.

\section{Combination studies in vitro}

The susceptibility tests of the combination of $(R)-(+)-\mathrm{CT}$ with the antifungal agents were also carried out based on the disk-diffusion method in solid media (OLIVEIRA et al., 2006, OSTROSKY et al., 2008).

In this test, the antifungal disks in their respective concentrations were soaked with $10 \mu \mathrm{L}$ of the MIC of $(R)-(+)-\mathrm{CT}$, and posteriorly dispensed in Petri dishes containing SDA inoculated with $1 \mathrm{~mL}$ of the fungal suspensions. Then, the dishes were incubated at $35 \pm 2^{\circ} \mathrm{C}$ for $24-48 \mathrm{~h}$. The interactions of the $(R)-$ $(+)-C T$ with the antifungal agents were considered as being positive (synergism), when the inhibition zone of the combined application was $(\geq 2 \mathrm{~mm})$ in relation to the antifungal medication alone, and as being negative (antagonism), when the inhibition zone of the association was $(\leq 2 \mathrm{~mm})$ to the presented by the isolated antifungal medication and " 0 interaction" (indifferent), when the inhibition 
zone of the combination was the same as the antifungal medication alone (CUENCAESTRELLA, 2004, CLEELAND, SQUIRES, 1991). The tests were carried out in duplicate and the results were expressed by the arithmetic mean of the diameters formed in the two tests in parallel.

\section{Statistical analysis}

For the statistical treatment the GraphPad Prism 6.0 software was used, and for the analysis between the columns the Student's t test was applied, and the results were considered significant when $p \leq 0.05$.

\section{RESULTS}

The results of the antifungal activity of the $(R)-(+)-C T$ against the $C$. albicans strains were determined using the MIC and MFC by microdilution in broth. The MIC values of the $(R)-(+)-\mathrm{CT}$ varied between 32 and $16 \mu \mathrm{g} / \mathrm{mL}$, however the latter corresponds to the inhibition of fungal growth in $90 \%$ of the tested strains (Table 1).

Table 1. $\mathrm{MIC}_{90}$ values $(\mu \mathrm{g} / \mathrm{mL})$ of $(R)-(+)$-CT against $C$. albicans strains by broth microdilution.

\begin{tabular}{|c|c|c|c|c|c|c|c|c|c|c|c|c|c|}
\hline Fungal strains / & $\mathbf{L M}$ & LM & LM & LM & LM & LM & LM & LM & LM & LM & LM & ATCC & ATCC \\
\hline Treatment & 852 & 157 & 152 & 240 & 0202 & 246 & 228 & 227 & 319 & 16 & 15 & 76485 & 76645 \\
\hline $1024 \mu \mathrm{g} / \mathrm{mL}$ & + & + & + & + & + & + & + & + & + & + & + & + & + \\
\hline $512 \mu \mathrm{g} / \mathrm{mL}$ & + & + & + & + & + & + & + & + & + & + & + & + & + \\
\hline $256 \mu \mathrm{g} / \mathrm{mL}$ & + & + & + & + & + & + & + & + & + & + & + & + & + \\
\hline $128 \mu \mathrm{g} / \mathrm{mL}$ & + & + & + & + & + & + & + & + & + & + & + & + & + \\
\hline $64 \mu \mathrm{g} / \mathrm{mL}$ & + & + & + & + & + & + & + & + & + & + & + & + & + \\
\hline $32 \mu \mathrm{g} / \mathrm{mL}$ & + & + & + & + & + & + & + & + & + & + & + & + & + \\
\hline $16 \mu \mathrm{g} / \mathrm{mL}$ & + & + & + & + & + & + & + & + & + & + & + & + & - \\
\hline Negative control & - & - & - & - & - & - & - & - & - & - & - & - & - \\
\hline Positive control & + & + & + & + & + & + & + & + & + & + & + & + & + \\
\hline
\end{tabular}

(+) inhibition (-) no inhibition

The MFC was of $32 \mu \mathrm{g} / \mathrm{mL}$, corresponding to the MIC $\times 2$ for $90 \%$ C. albicans population as can be observed in (Table 2).

The results of the fungal susceptibility tests for $C$. albicans for the standard antifungal agents were determined by the disk-diffusion test in solid mean. The resistance profile was observed for 12 $(92.30 \%)$ of the fungal strains to the fluconazole and to itraconazole. However, for ketoconazole and miconazole the resistance was of $4(30.76 \%)$ and 3 $(23.07 \%)$ of the strains respectively (Table 3 ).

Table 2. $\mathrm{MFC}_{90}$ values $(\mu \mathrm{g} / \mathrm{mL})$ of $(R)-(+)-\mathrm{CT}$ against $C$. albicans strains.

\begin{tabular}{|c|c|c|c|c|c|c|c|c|c|c|c|c|c|}
\hline $\begin{array}{l}\text { Fungal strains / } \\
\text { Treatment }\end{array}$ & $\begin{array}{l}\text { LM } \\
852\end{array}$ & $\begin{array}{l}\text { LM } \\
157\end{array}$ & $\begin{array}{l}\text { LM } \\
152\end{array}$ & $\begin{array}{l}\text { LM } \\
240\end{array}$ & $\begin{array}{c}\text { LM } \\
\mathbf{0 2 0 2}\end{array}$ & $\begin{array}{l}\mathrm{LM} \\
246\end{array}$ & $\begin{array}{l}\text { LM } \\
228\end{array}$ & $\begin{array}{l}\text { LM } \\
227\end{array}$ & $\begin{array}{l}\text { LM } \\
319\end{array}$ & $\begin{array}{c}\mathrm{LM} \\
16\end{array}$ & $\begin{array}{c}\mathrm{LM} \\
\mathbf{1 5}\end{array}$ & $\begin{array}{c}\text { ATCC } \\
76485\end{array}$ & $\begin{array}{r}\text { ATCC } \\
76645\end{array}$ \\
\hline $1024 \mu \mathrm{g} / \mathrm{mL}$ & + & + & + & + & + & + & + & + & + & + & + & + & + \\
\hline $512 \mu \mathrm{g} / \mathrm{mL}$ & + & + & + & + & + & + & + & + & + & + & + & + & + \\
\hline $256 \mu \mathrm{g} / \mathrm{mL}$ & + & + & + & + & + & + & + & + & + & + & + & + & + \\
\hline $128 \mu \mathrm{g} / \mathrm{mL}$ & + & + & + & + & + & + & + & + & + & + & + & + & + \\
\hline $64 \mu \mathrm{g} / \mathrm{mL}$ & + & + & + & + & + & + & + & + & + & + & + & + & + \\
\hline $32 \mu \mathrm{g} / \mathrm{mL}$ & + & + & + & + & + & + & + & + & + & + & - & + & + \\
\hline Negative control & - & - & - & - & - & - & - & - & - & - & - & - & - \\
\hline Positive control & + & + & + & + & + & + & + & + & + & + & + & + & + \\
\hline
\end{tabular}

(+) inhibition (-) no inhibition

Table 3. Susceptibility testing of $C$. albicans strains to standard antifungal. Average diameters of halos expressed in (mm).

\begin{tabular}{lcccccccccccccc}
\hline Fungal strains / & LM & LM & LM & LM & LM & LM & LM & LM & LM & LM & LM & ATCC & ATCC & Classification \\
Treatment & $\mathbf{8 5 2}$ & $\mathbf{1 5 7}$ & $\mathbf{1 5 2}$ & $\mathbf{2 4 0}$ & $\mathbf{0 2 0 2}$ & $\mathbf{2 4 6}$ & $\mathbf{2 2 8}$ & $\mathbf{2 2 7}$ & $\mathbf{3 1 9}$ & $\mathbf{1 6}$ & $\mathbf{1 5}$ & $\mathbf{7 6 4 8 5}$ & $\mathbf{7 6 6 4 5}$ & \\
\hline KET $(50 \mu \mathrm{g})$ & $14^{* *}$ & $0^{* *}$ & $22^{*}$ & $25^{*}$ & $22^{*}$ & $25^{*}$ & $24^{*}$ & $22^{*}$ & $20^{* *}$ & $12^{* *}$ & $22^{*}$ & $26^{*}$ & $26^{*}$ & $>20(\mathrm{~S}) \leq 20(\mathrm{R})$ \\
FLU $(25 \mu \mathrm{g})$ & $0^{* *}$ & $0^{* *}$ & $12^{* *}$ & $0^{* *}$ & $0^{* *}$ & $17^{* *}$ & $20^{*}$ & $0^{* *}$ & $16^{* *}$ & $0^{* *}$ & $0^{* *}$ & $0^{* *}$ & $0^{* *}$ & $\geq 20(\mathrm{~S})<20(\mathrm{R})$ \\
ICZ $(10 \mu \mathrm{g})$ & $0^{* *}$ & $0^{* *}$ & $0^{* *}$ & $15^{* *}$ & $0^{* *}$ & $18^{* *}$ & $20^{*}$ & $12^{* *}$ & $18^{* *}$ & $12^{* *}$ & $0^{* *}$ & $16^{* *}$ & $13^{* *}$ & $\geq 20(\mathrm{~S})<20(\mathrm{R})$ \\
MCZ $(50 \mu \mathrm{g})$ & $23^{*}$ & $22^{*}$ & $27^{*}$ & $23^{*}$ & $20^{* *}$ & $30^{*}$ & $30^{*}$ & $22^{*}$ & $20^{* *}$ & $24^{*}$ & $25^{*}$ & $20^{* *}$ & $28^{*}$ & $>20(\mathrm{~S}) \leq 20(\mathrm{R})$ \\
Control yeast & + & + & + & + & + & + & + & + & + & + & + & + & + & -- \\
\hline
\end{tabular}

${ }^{*}$ Sensible (S); ${ }^{* * *}$ Resistant (R), KET (Ketoconazole); FLU (Fluconazole); ICZ (Itraconazole); MCZ (Miconazole)

The results for the combination tests are shown in the (Table 4), where can be observed that the effects of the $(R)-(+)-C T$ interference on the antifungal medications varied according to the type 
of the therapeutic agent and the fungal strain tested. However, synergism was predominant on the four tested antifungal medications. The association of the $(R)-(+)-\mathrm{CT}$ with ketoconazole, as well as to miconazole, resulted respectively in synergetic effect in $13(100 \%)$ of the fungal strains. The $(R)$ $(+)-C T$ in combination with fluconazole showed synergism in $11(84.61 \%)$ of the yeast, and in association with itraconazole $9(69.23 \%)$.

Table 4. Average diameters (in $\mathrm{mm})$ of the test $(R)-(+)-\mathrm{CT}$ combination of patterns and antifungal against $C$. albicans in solid medium.

\begin{tabular}{lccccccccccccc}
\hline Fungal strains / & LM & LM & LM & LM & LM & LM & LM & LM & LM & LM & LM & ATCC & ATCC \\
Treatment & $\mathbf{8 5 2}$ & $\mathbf{1 5 7}$ & $\mathbf{1 5 2}$ & $\mathbf{2 4 0}$ & $\mathbf{0 2 0 2}$ & $\mathbf{2 4 6}$ & $\mathbf{2 2 8}$ & $\mathbf{2 2 7}$ & $\mathbf{3 1 9}$ & $\mathbf{1 6}$ & $\mathbf{1 5}$ & $\mathbf{7 6 4 8 5}$ & $\mathbf{7 6 6 4 5}$ \\
\hline KET $(50 \mu \mathrm{g})$ & $25 \uparrow$ & $50 \uparrow$ & $35 \uparrow$ & $45 \uparrow$ & $40 \uparrow$ & $45 \uparrow$ & $42 \uparrow$ & $35 \uparrow$ & $40 \uparrow$ & $34 \uparrow$ & $40 \uparrow$ & $50 \uparrow$ & $45 \uparrow$ \\
FLU $(25 \mu \mathrm{g})$ & $20 \uparrow$ & $25 \uparrow$ & $20 \uparrow$ & $25 \uparrow$ & $12 \uparrow$ & $20 \uparrow$ & $25 \uparrow$ & $0 \mathrm{I}$ & $14 \downarrow$ & $20 \uparrow$ & $20 \uparrow$ & $30 \uparrow$ & $30 \uparrow$ \\
ICZ $(10 \mu \mathrm{g})$ & $20 \uparrow$ & $0 \mathrm{I}$ & $25 \uparrow$ & $15 \mathrm{I}$ & $20 \uparrow$ & $24 \uparrow$ & $20 \mathrm{I}$ & $15 \uparrow$ & $20 \uparrow$ & $25 \uparrow$ & $17 \uparrow$ & $25 \uparrow$ & $0 \downarrow$ \\
MCZ $(50 \mu \mathrm{g})$ & $40 \uparrow$ & $35 \uparrow$ & $42 \uparrow$ & $35 \uparrow$ & $42 \uparrow$ & $40 \uparrow$ & $35 \uparrow$ & $35 \uparrow$ & $45 \uparrow$ & $40 \uparrow$ & $35 \uparrow$ & $40 \uparrow$ & $35 \uparrow$ \\
Control yeast & + & + & + & + & + & + & + & + & + & + & + & + & + \\
\hline
\end{tabular}

$\uparrow$ Synergism; $\downarrow$ Antagonism; I Indifferent

Furthermore, it was also observed that for some of the strains previously resistant to isolated antifungal medications, became sensitive when faced with the combination of the phytoconstituent with the antifungal agents.
For ketoconazole, the strains that suffered exchange of profile from resistant to sensitive were C. albicans LM 852, LM 157, LM 319 and LM 16 (Table 3, 4 and Figure 2).

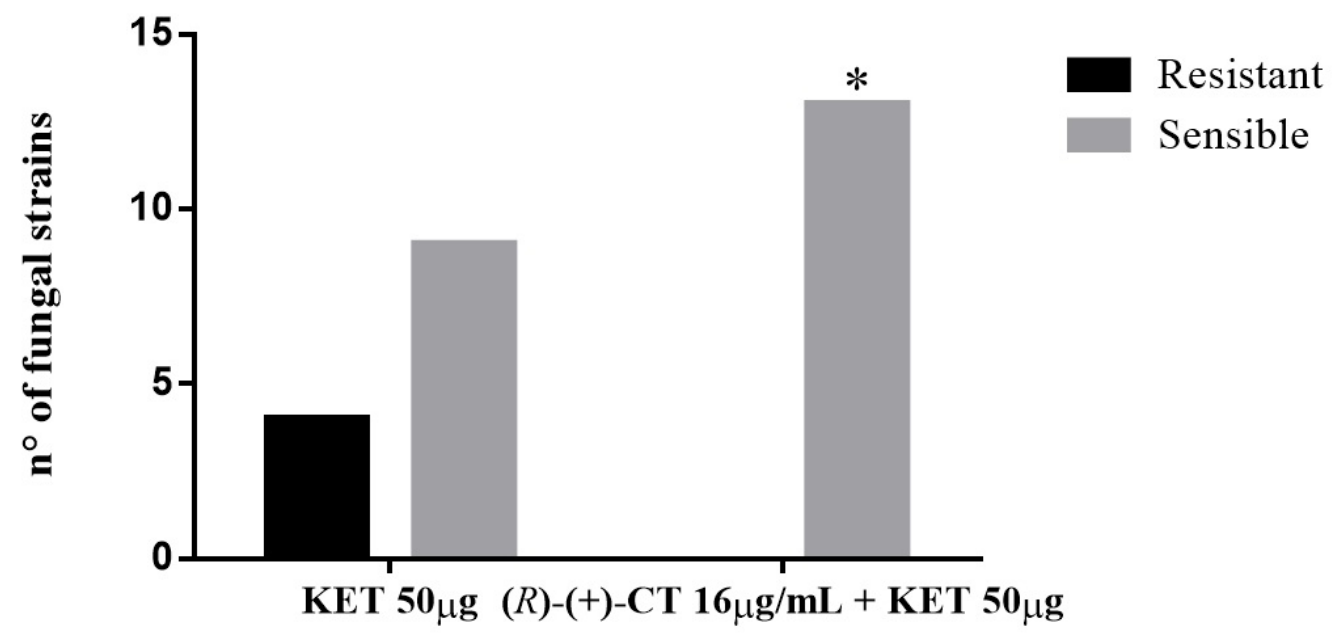

\section{Treatment}

Figure 2. Resistance profile and sensitivity of $C$. albicans front ketoconazole and in combination with $(R)-(+)-$ $\mathrm{CT},{ }^{*} p \leq 0.05$.

For the fluconazole, the combination with $(R)-(+)-\mathrm{CT}$ resulted in the change of resistance profile from resistant to sensitive of the following strains of C. albicans: LM 852, LM 157, LM 152, LM 240, LM 246, LM 16, LM 15, ATCC 76485 and ATCC 76645 (Table 3, 4 and Figure 3).

For the itraconazole, the effect of the combination with the phytoconstituent resulted in the change of the resistance profiles of the following yeasts: LM 852, LM 152, LM 0202, LM 246, LM 319, LM 16 and ATCC 76485 (Table 3, 4 and Figure 4).

As for the miconazole, there was a change of the resistance profile in three strains as a consequence of the combination of the $(R)-(+)-\mathrm{CT}$ with the antifungal agent: LM 0202, LM 319 and ATCC 76485 (Table 3, 4 and Figure 5). 


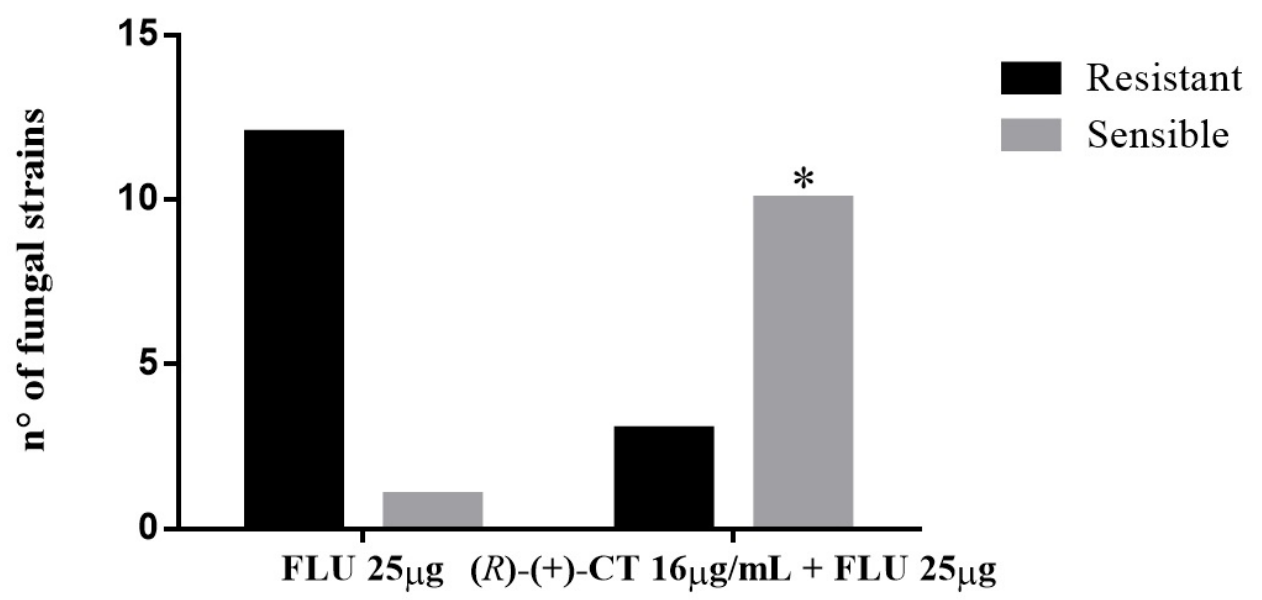

\section{Treatment}

Figure 3. Resistance profile and sensitivity of $C$. albicans front fluconazole and in combination with $(R)-(+)-$ $\mathrm{CT},{ }^{*} p \leq 0.05$.

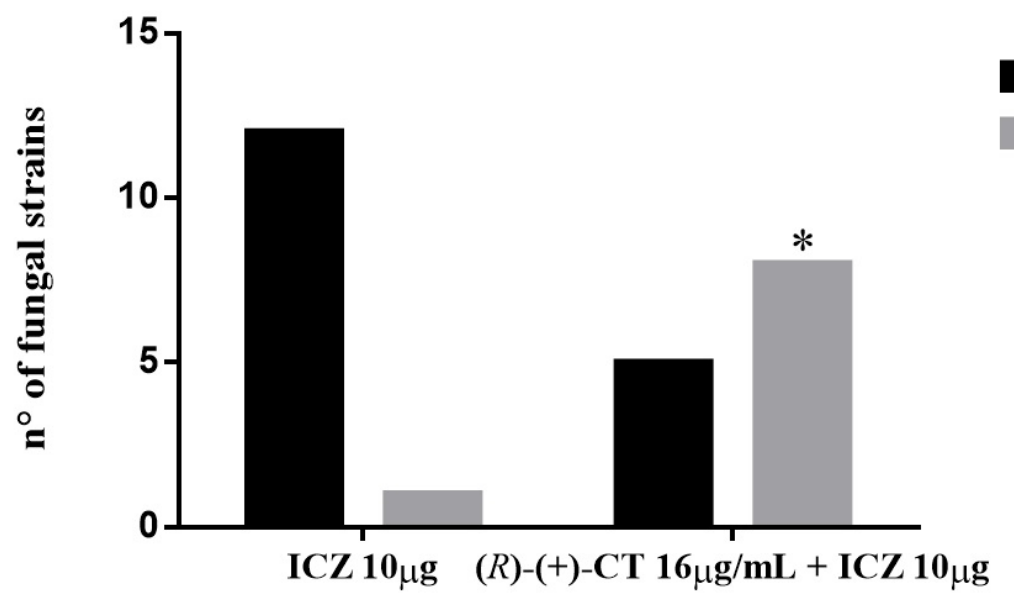

Treatment

Figure 4. Resistance profile and sensitivity of $C$. albicans front itraconazole and in combination with $(R)-(+)-$ $\mathrm{CT},{ }^{*} p \leq 0.05$.

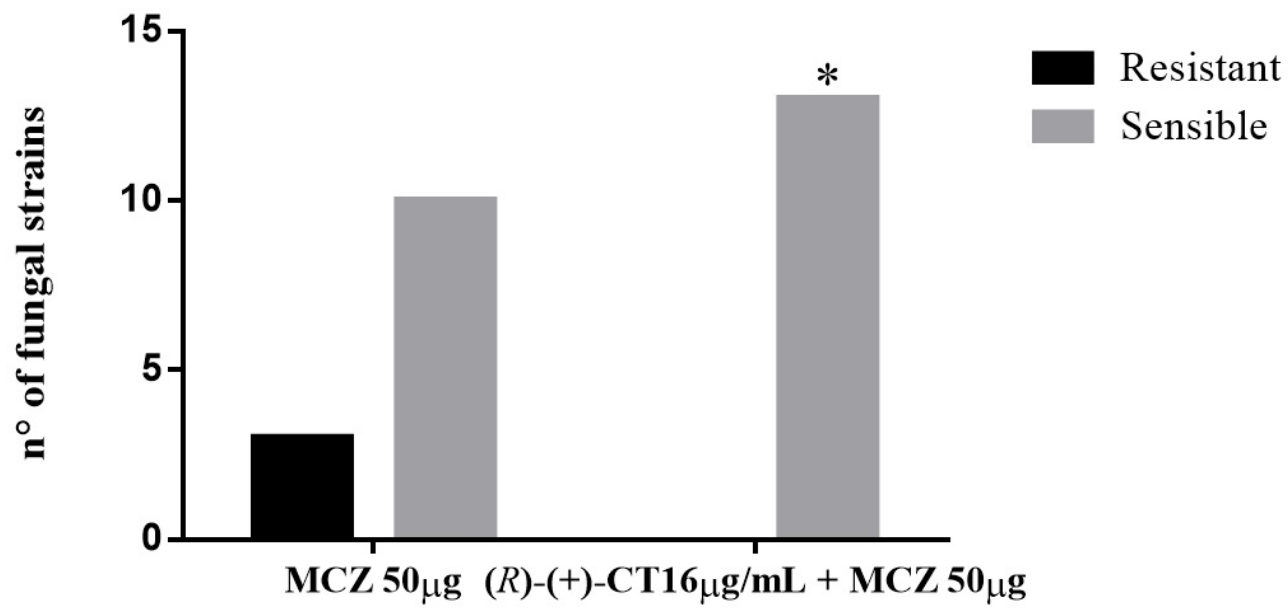

\section{Treatment}

Figure 5. Resistance profile and sensitivity of $C$. albicans front miconazole and in combination with $(R)-(+)-$ $\mathrm{CT},{ }^{*} p \leq 0.05$. 


\section{DISCUSSION}

The high incidence of infections by $C$. albicans and the emergence of resistance to the antifungal drugs accentuates the need of studying new sources of drugs, such as natural products and their phytoconstituents (LIMA et al., 2012).

Herbal substances are used in the treatment of several diseases, but their application as a potential source of new drugs is still very little exploited. Of the 250.000 to 500.000 plant species, only a small percentage have had, their pharmacological properties studied (RATES, 2001). Thus, the compounds derived from plants are potential sources of new and valuable therapeutic agents (TROMBETTA et al., 2005, SINGH et al., 2011). Therefore, the phytoconstituents are important, due to the various pharmacological activities such as the antifungal, antibacterial and antiparasitic (OLAGNIER et al., 2007, CARDOSO et al., 2010, ZORE et al., 2011a).

The terpenoids such as the $(R)-(+)-\mathrm{CT}$, a major phytoconstituent of the essential oils of plants of the genus Cymbopogon and Eucalyptus presents excellent antifungal activity (AVOSEH et al., 2015, BATUBARA et al., 2015). In this study, it was observed that the $(R)-(+)-\mathrm{CT}$ showed excellent antifungal efficiency in $90 \%$ of the $C$. albicans strains. According to the criteria of Morales et al., 2008, this phytoconstituent showed strong anti-C. albicans activity because the value of the $\mathrm{MIC}_{90}$ was less than $100 \mu \mathrm{g} / \mathrm{mL} \quad(\mathrm{MIC}<100 \mu \mathrm{g} / \mathrm{mL}$ ). In literature, $(R)-(+)-\mathrm{CT}$, also showed to have a good fungicide, bactericidal, trypanocidal and leishmanicidal activity (ZORE et al., 2011b, PEREIRA et al., 2015).

In this work, the fungicide effect of the $(R)$ (+)-CT was also verified in $90 \%$ of the $C$. albicans strains $\left(\mathrm{MFC}_{90}=32 \mu \mathrm{g} / \mathrm{mL}\right)$. According to Hafidh et al., 2011 the fungicide effect of a natural product such as the citronellal, is observed when the coefficient between the MFC/MIC is between 1 and 2.

The treatment recommendations for VVC are separated into simple treatment, caused by $C$. albicans and complicated $\mathrm{VVC}$, which includes RVVC, and severe VVC caused by non-albicans species, and VVC in immunocompromised hosts (WORKOWSKI, BERMAN, 2006, JACK, SOBEL, 2016).

The good performance evidenced for the ketoconazole and the miconazole, against $C$. albicans has already been observed, and the oral administration of ketoconazole has proved to be efficient against RVVC when faced with strains susceptible to the azoles in the maintenance therapy (SOBEL, 1985). However, due to the hepatic toxicity mainly to the ketoconazole, other therapeutic schemes are now preferred (LEWIS et al., 1984).

In this context, it has been observed that for the ketoconazole and the miconazole, C. albicans presents a good sensitivity, as shown in (Table 3). However, the presence of 30.76 and $23.07 \%$ of resistance to the $C$. albicans strains in this study emphasizes the change to a lower susceptibility to these antifungal medications (DALAZEN et al., 2011). Therefore, the high frequency of resistance to the triazolic drugs worked in this study, demonstrates a growing profile of resistance to the genus Candida (RUIZ-CAMPS, CUENCAESTRELLA, 2009).

For more than one decade, cases of reduced sensitivity to the fluconazole and itraconazole have been observed (MÍMICA et al., 2009, FAVALESSA et al., 2010), with the observation of cross-resistance to isolated $C$. albicans and nonalbicans, by the previous and prolonged exposure to the fluconazole (NUNES et al., 2011). However, a lower susceptibility to the fluconazole and itraconazole has been observed, reported in vulvovaginal clinical samples (Table 3) (DALAZEN et al., 2011, ABACI, HALIKIUZTAN, 2011). This way, C. albicans has shown to be predominantly resistant resembling the profile of this work (SPAMPINATO, LEONARDI, 2013).

In view of this context, the reality of the current clinical situation of the emerging cases of antimicrobial resistance, the treatment of infections by $C$. albicans and several other microorganisms has become more difficult, reflecting in a higher frequency of therapeutic failure to the monotherapy (AHMAD et al., 2010).

In these cases, the research of the interactions of natural and synthetic products on the effectiveness of the conventional antifungal medications seems to us as being quite promising if the combination results in a better activity spectrum and reduced toxicity in comparison to complementary schemes of a single agent (ROLING et al., 2002, AHMAD et al., 2010). This way, it seems that the modification of the antimicrobial activity resulting from the associations, with the expansion of the sensitivity profile of resistant fungal strains shows to be a new strategy in clinical practice, with the potential of being a modifier of the resistance profile (CUENCA-ESTRELLA, 2004, OLIVEIRA et al., 2006, SOUSA et al., 2011, RIBEIRO et al., 2013). 
The terpenoids' mechanisms of antiCandida activity are not very clear, but have been reported to modulate the mevalonate pathway (MP), alter the cellular levels of intermediate molecules and functions associated in eukaryotic cells (BREHM-STECHER, JOHNSON, 2003). In addition to the modulation of the MP, terpenoids have been reported to destabilise the membrane and modular functions associated to the membrane, such as permeability, cell signaling, leading to cell death (TROMBETTA et al., 2005; ZORE et al., 2011a), (BREHM-STECHER, JOHNSON, 2003; MO, ELSON, 2004; GOULART et al., 2004).

The terpenoids have also been reported to detain the cell cycle in eukaryotic cells, and the citronellal detains the cell cycle of $C$. albicans in the DNA duplication phase, called $S$ phase (Zore et al., 2011a; BREHM-STECHER, JOHNSON，2003; MO, ELSON, 2004; GOULART et al., 2004).

It is probable that due to the level of lipophilicity, the $(R)-(+)-\mathrm{CT}$ has interacted with the components of the fungal membrane's phospholipid bilayer therefore affecting, the degree of fluidity, besides interfering in signaling routes involved in the synthesis of polysaccharides such as the $\beta$ glucan, mannan and chitin, important for the maintenance of the $C$. albicans cell wall. Therefore, these interactions may cause a greater influx of antifungal agents, resulting in the increase of the inhibition zones and thus reducing the resistances of these yeasts (Table 4) (SANCHEZET et al., 2004; BRAGA et al., 2007; ZORE et al., 2011b).

\section{CONCLUSION}

Citronellal has a promising fungicide activity, being capable of inhibiting an infection still in its initial stage. In addition, this monoterpene $(R)$ $(+)$-CT has shown to act synergically with ketoconazole, miconazole, fluconazole and itraconazole. Thus, this tested compound may become an alternative in the monotherapeutic antifungal chemotherapy for VVC and RVVC or in combination with conventional drugs. However, there is a need for more studies aimed to correlate its potent antifungal activity in vitro and in vivo proving its security for clinical application.

\section{ACKNOWLEDGEMENTS}

The authors thank the Federal University of Paraiba and CAPES for the structural and financial support for the implementation of this work. The Deborah Medcraft the translation of the article.

RESUMO: Candidíase vulvovaginal (CVV) é uma infecção fúngica comum que afeta mulheres saudáveis de todas as idades. Pelo menos $75 \%$ das mulheres irão desenvolver uma ou mais infecções uma vez durante a vida, com 6 a $9 \%$ dos indivíduos desenvolvendo infecções recorrentes. Diante deste contexto, buscou-se avaliar neste estudo o potencial antifúngico do $(R)-(+)$-citronelal $[(R)-(+)-C T]$ isolado e associado a agentes terapêuticos de importância clínica. O enantiômero foi solubilizado em tween 80 e dimetilsulfóxido (DMSO). Posteriormente diluiu-se em água destilada estéril até a concentração de $2048 \mu \mathrm{g} / \mathrm{mL}$. A concentração inibitória mínima (CIM) do produto foi determinada por microdiluição em meio RPMI-1640 obtendo diluições de 4-1024 $\mu \mathrm{g} / \mathrm{mL}$. A concentração fungicida mínima (CFM) foi determinada pela técnica de esgotamento em agar Sabouraud dextrose (ASD) a partir de alíquotas de $1 \mathrm{~mL}$ da CIM, CIM $\times 2$ e CIM $\times 4$. A CIM e a CFM do $(R)-(+)-C T$ para $90 \%$ das cepas de $C$. albicans foram 16 e $32 \mu \mathrm{g} / \mathrm{mL}$ respectivamente. No ensaio de suscetibilidade, $C$. albicans apresentou alta resistência ao fluconazol e ao itraconazol, 12 (92.30\%) das cepas. No em tanto, para o cetoconazol e o miconazol a resistência foi de $4(30.76 \%)$ e $3(23.07 \%)$ das cepas respectivamente. No ensaio de combinação do $(R)-(+)$-CT com cetoconazol e miconazol, a resistência foi completamente revertida. Para o fluconazol e o itraconazol, a resistências foi revertida em $9(75 \%)$ e $7(58.33 \%)$ das cepas respectivamente. O $(R)-(+)$-CT apresentou atividade fungicida com $\mathrm{CFM}$ igual à $\mathrm{CIM} \times 2$. Quando em combinação com cetoconazol, fluconazol, itraconazol e miconazol ampliou as zonas de inibição desses antifúngicos, diminuindo a resistência contra C. albicans.

\section{Citronelal}

PALAVRA-CHAVE: Monoterpenoide. Anti-C. albicans. Agentes antifúngicos. Metabólitos secundários.

\section{REFERENCES}

ABACI, O.; HALIKI-UZTAN, A. Investigation of the susceptibility of Candida species isolated from denture wearers to different antifungal antibiotics. Afr. J. Microbiol. Res., v. 5, n. 12, p. 1398-1403, 2011.

https://doi.org/10.5897/AJMR10.693 
ADESIJI, Y. O.; NDUKWE, N.; OKANLAWON, B. M. Isolation and antifungal sensitivity to Candida isolates in young females. Cent. Eur. J. Med., v. 6, n. 2, p. 172-176, 2011. https://doi.org/10.2478/s11536-010-0071-0

AHMAD, A.; KHAN, A.; KHAN, L. A.; MANZOOR, N. In vitro synergy of eugenol and methyleugenol with fluconazole against clinical Candida isolates. J. Med. Microbiol., v. 59, n. 10, p. 1178-1184, 2010. https://doi.org/10.1099/jmm.0.020693-0

AVOSEH, O.; OYEDEJI, O.; RUNGQU, P.; NKEH-CHUNGAG, B.; OYEDEJI, A. Cymbopogon Species; Ethonopharmacology, Phytochemistry and the Pharmacological Importance. Molecules. v. 20, n. 5, p. 74387453, 2015. https://doi.org/10.3390/molecules20057438

BATUBARA, I.; SUPARTO, I. H.; SA’DIAH, S.; MATSUOKA, R.; MITSUNAGA, T. Effects of Inhaled Citronella Oil and Related Compounds on Rat Body Weight and Brown Adipose Tissue Sympathetic Nerve. Nutrients. v. 7, n. 3, p. 1859-1870, 2015. https://doi.org/10.3390/nu7031859

BAUER, A. W.; KIRBY, W. M.; SHERRIS, J. C.; TURCK, M. Antibiotic susceptibility testing by a standardized single disk method. Am. J. Clin. Pathol., v. 45, n. 4, p. 493-496, 1966.

BEHZADI, P.; BEHZADI, E.; RANJBAR, R. Urinary tract infections and Candida albicans. Cent. European. J. Urol., v. 68, n. 1, p. 96-101, 2015. https://doi.org/10.5173/ceju.2015.01.474

BRAGA, P. C.; ALFIERI, M.; CULICI, M.; DAL SASSO, M. Inhibitory activity of thymol against the formation and viability of Candida albicans hyphae. Mycoses. v. 50, n. 6, p. 502-506, 2007. https://doi.org/10.1111/j.1439-0507.2007.01412.x

BREHM-STECHER, B. F.; JOHNSON, E. A. Sensitization of Staphylococcus aureus and Escherichia coil to antibiotics by the sequiterpenoids, nerolidol, farnesol, bisabolol and apritone. Antimicrob. Agents Ch. v. 47, n. 10, p. 3357-3360, 2003. https://doi.org/10.1128/AAC.47.10.3357-3360.2003

BRITO, D. R.; OOTANI, M. A.; RAMOS, A. C. C.; COSTA SERTÃO, W.; AGUIAR, R. W. S. Efeito dos óleos de citronela, eucalipto e composto citronelal sobre microflora e desenvolvimento de plantas de milho. J. Biotec. Biodivers. v. 3, n. 4, p. 184-192, 2012.

BRUNI, R.; MEDICI, A.; ANDREOTTI, E.; FANTIN, C.; MUZZOLI, M.; DEHESA, M.; ROMAGNOLI, C.; SACCHETTI, G. Chemical composition and biological activities of Ishpingo essential oil, a traditional Ecuadorian spice from Ocotea quixos (Lam.) Kosterm (Lauraceae) flower calices. Food Chemistry. v. 85, n. 1, p. 415-421, 2004. https://doi.org/10.1016/j.foodchem.2003.07.019

CARDOSO, J.; SOARES, M. J. In vitro effects of citral on Trypanosoma cruzi metacyclogenesis. Mem. Inst. Oswaldo Cruz. v. 105, n. 8, p. 1026-1032, 2010. https://doi.org/10.1590/S0074-02762010000800012

CLEELAND, R.; SQUIRES, E. Evaluation of new antimicrobials in vitro and in experimental animal infections. Antibiot. Lab. Med., v. 3, p. 739-787, 1991.

CLINICAL AND LABORATORY STANDARDS INSTITUTE, Method for Antifungal Disk Diffusion Susceptibility Testing of Yeasts; Approved Guideline. 2. ed. CLSI document M44-A2. Wayne, PA: Clinical and Laboratory Standards Institute; 2009.

CUENCA-ESTRELLA, M. Combinations of antifungal agents in therapy-what value are they?. J. Antimicrob. Chemoth., v. 54, n. 5, p. 854-869, 2004. https://doi.org/10.1093/jac/dkh434

DALAZEN, D.; ZANROSSO, D.; WANDERLEY, L.; SILVA, N. L.; FUENTEFRIA, A. M. Comparação do perfil de suscetibilidade entre isolados clínicos de Candida spp. orais e vulvovaginais no Sul do Brasil. J. Bras. Patol. Med. Lab., v. 47, n. 1, p. 33-38, 2011. https://doi.org/10.1590/S1676-24442011000100004 
DOVNIK, A.; GOLLE, A.; NOVAK, D.; ARKO, D.; TAKAČ, I. Treatment of vulvovaginal candidiasis: a review of the literature. Acta Dermatovenerolgica. v. 24, n. 1, p. 5-7, 2015.

https://doi.org/10.15570/actaapa.2015.2

ERNST, M. E.; KLEPSER, M. E.; WOLFE, E. J.; PFALLER, M. A. Antifungal dynamics of LY 303366, an investigational echinocandin B analog, against Candida ssp. Diagn. Micr. Infec. Dis., v. 26, n. 3-4, p. 125-131, 1996. https://doi.org/10.1016/S0732-8893(96)00202-7

ESPINEL-INGROFF, A.; CHATURVEDI, V.; FOTHERGILL, A.; RINALDI, M. G. Optimal testing conditions for determining MICs and minimum fungicidal concentrations of new and established antifungal agents for uncommon molds: NCCLS collaborative study. J. Clin. Microbiol., v. 40, n. 10, p. 3776-3781, 2002. https://doi.org/10.1128/JCM.40.10.3776-3781.2002

ESPINEL-INGROFF, A. Mechanisms of resistance to antifungal agents: Yeasts and filamentous fungi. Rev. Iberoam. Micol., v. 25, n. 2, p. 101-106, 2008. https://doi.org/10.1016/S1130-1406(08)70027-5

FAVALESSA, O. C.; MARTINS, M. A.; HAHN, R. C. Aspectos micológicos e suscetibilidade in vitro de leveduras do gênero Candida em pacientes HIV-positivos provenientes do Estado de Mato Grosso. Rev. Socied. Bras. Med. Trop., v. 43, n. 6, p. 673-677, 2010. https://doi.org/10.1590/S0037-86822010000600014

FOXMAN, B.; MURAGLIA, R.; DIETZ, J. P.; SOBEL, J. D.; WAGNER, J. Prevalence of recurrent vulvovaginal candidiasis in 5 European countries and the United States: results from in internet panel survey. J. Low Genit. Tract Dis., v. 17, n. 3, p. 340-345, 2013. https://doi.org/10.1097/LGT.0b013e318273e8cf

GANDHI, T. N.; PATEL, M. G.; JAIN, P. M. R. Antifungal Susceptibility of Candida Against Six Antifungal Drugs by Disk Diffusion Method Isolated from Vulvovaginal Candidiasis. Int. J. Cur. Res. Rev., v. 7, n. 11, p. 20-25, 2015.

GOULART, H. R.; KIMURA, E. A.; PERES, V. J.; COUTO, A. S.; AQUINO DUARTE, F. A.; KATZIN, A. M. Terpenes arrest parasite development and inhibit biosynthesis of terpenoids in Plasmodium falciparum. Antimicrob Agents Chemother., v. 48, n. 7, p. 2502-2509, 2004. https://doi.org/10.1128/AAC.48.7.25022509.2004

HADACEK, F.; GREGER, H. Testing of antifungal natural products: methodologies, comparability of results and assay coices. Phytochem Analysis. v. 11, n. 3, p. 137-147, 2000. https://doi.org/10.1002/(SICI)10991565(200005/06)11:3<137::AID-PCA514>3.0.CO;2-I

HAFIDH, R. R.; ABDULAMIR, A. S.; VERN, L. S.; ABU BAKAR, F.; JAHANSHIRI, F.; SEKAWI, Z. Inhibition of Growth of Highly Resistant Bacterial and Fungal Pathogens by a Natural Product. The Open Microbiol. J., v. 5, n. 1, p. 96-106, 2011. https://doi.org/10.2174/1874285801105010096

HEMAISWARYA, S. H.; KRUTHIVENTI, A. K.; DOBLE, M. Synergism between natural products and antibiotics against diseases. Phytomedicine. v. 15, n. 1, p. 639-652, 2008.

https://doi.org/10.1016/j.phymed.2008.06.008

HONG, E.; DIXIT, S.; FIDEL, P. L.; BRADFORD, J.; FISCHER, G. Vulvovaginal candidiasis as a chronic disease: diagnostic criteria and definition. J. Low Genit. Tract Dis., v. 18, n. 1, p. 31-38, 2014. https://doi.org/10.1097/LGT.0b013e318287aced

HOOD, J. R.; WILKINSON, J. M.; CAVANAGH, H. M. A. Evaluation of common antibacterial screening methods utilized in essential oil research. J. Essential Oil Res., v. 15, n. 6, p. 428-433, 2003.

https://doi.org/10.1080/10412905.2003.9698631

JACK, D.; SOBEL, M. D. Recurrent vulvovaginal candidiasis. Am. J. Obstet. Gynecol., v. 214, n.1, p. 15-21, 2016. https://doi.org/10.1016/j.ajog.2015.06.067 
KONEMAN, E. W; ALLEN, S. D.; JANDA, W. M.; SCHRECKENBERGER, P. C.; WIN, W. C. J. Diagnóstico Microbiológico. 6 ed. São Paulo: Médica e Científica Ltda, 2008. p. 1565.

KONEMAN, E. W.; ALLEN, S. D.; DOWEL-JÚNIOR, V. R.; SAMERS, H. M. Diagnóstico Microbiológico. 2.ed. Texto Atlas. Editora Médica Pan Americana, 1993, p. 452-485.

LEWIS, J. H.; ZIMMERMAN, H. J.; BENSON, G. D.; ISHAK, K. G. Hepatic injury associated with ketoconazole therapy. Analysis of 33 cases. Gastroenterology. v. 86, n. 3, p. 503-513, 1984.

LI, J.; SHAN, Y.; FAN, S.; LIU, X. Prevalence of Candida nivariensis and Candida bracarensis in Vulvovaginal Candidiasis. Mycopathologia. v. 178, n. 1, p. 279-283, Aug. 2014.

https://doi.org/10.1007/s11046-014-9800-2

LIMA, I. O.; NÓBREGA, F. M.; OLIVEIRA, W. A.; LIMA, E. O.; MENEZES, E. A.; AFRÂNIO CUNHA, F.; MELO DINIZ, M. F. F. Anti-Candida albicans effectiveness of citral and investigation of mode of action. Pharm. Biol., v. 50, n. 12, p. 1536-1541, 2012. https://doi.org/10.3109/13880209.2012.694893

LORENZI, V.; MUSELLI, A.; BERNARDINI, A.; BERTI L PAGÈS, J. M.; AMARAL, L.; BOLLA, J. M. Geraniol restores antibiotic activities against multidrug-resistant isolates from Gram Negative species. Antimicrob Agents Chemother., v. 53, n. 5, p. 2209-2211, 2009. https://doi.org/10.1128/AAC.00919-08

MÍMICA, L. M. J.; UEDA SMY, MARTINO, M. D. V.; NAVARINI, A.; MARTINI, I. J. Diagnóstico de infecção por Candida: avaliação de testes de identificação de espécies e caracterização do perfil de suscetibilidade J. Bra. Patolo. Med. Lab., v. 45, n. 1, p. 17-23, 2009.

MO, H.; ELSON, C. C. Studies on the isoprenoid-mediated inhibition of mevalonate synthesis applied to cancer chemotherapy and chemoprevention. Exp. Biol. Med., v. 229, n. 7, p. 567-585, 2004.

MONDELLO, F.; BERNARDIS, F. D.; GIROLAMO, A.; CASSONE, A.; SALVATORE, G. In vivo activity of terpinen-4-ol, the main bioactive component of Melaleuca alternifólia Cheel (tea tree) oil against azolesusceptible and -resistant human pathogenic Candida species. BMC Infect. Dis., v. 6, n. 1, p. 158-165, 2006. https://doi.org/10.1186/1471-2334-6-158

MORALES, G.; PAREDES, A.; SIERRA, P.; LOYOLA, L. A. Antimicrobial activity of three baccharis species used in the traditional medicine of Northern Chile. Molecules. v. 13, n. 4, p. 790-794, 2008. https://doi.org/10.3390/molecules 13040790

NATTINAL COMMITTEE FOR CLINICAL LABORATORY STANDARDS (NCCLS), 2002. Reference method for broth dilution antifungal susceptibility testing of yeasts. Villanova, NCCLS, v. 17, n.9 (Document M27-A2).

NASCIMENTO, P. F. C.; NASCIMENTO, A. C.; RODRIGUES, C. S.; ANTONIOLLI, A. R.; SANTOS, M. P. O.; JÚNIOR, A. M. B., TRINDADE, R. C. Atividade antimicrobiana dos óleos essenciais: uma abordagem multifatorial dos métodos. Rev. Bra. Farmacog., v. 17, n. 1, p. 108-113, 2007. https://doi.org/10.1590/S0102695X2007000100020

NUNES, E. B.; MONTEIRO, J. C. M. S.; NUNES, N. B.; VAZ PAES, L. Antifungal sensitivity profile for the Candida genus in a reference hospital in Northern Brazil. Rev. Pan-Amazônica de Saúde. v. 2, n. 4, p. 23-30, 2011. https://doi.org/10.5123/S2176-62232011000400004

OLAGNIER, D.; COSTES, P.; BERRY, A.; LINAS, M. D.; URRUTIGOITY, M.; DECHY-CABARET, O.; BENOIT-VICAL, F. Modifications of the chemical structure of terpenes in antiplasmodial and antifungal drug research. Bioorg. Med. Chem. Lett., v. 17 n. 1, p. 6075-6078, 2007. https://doi.org/10.1016/j.bmcl.2007.09.056 
OLIVEIRA, R. A. G.; LIMA, E. O.; VIERA, W. L.; FREIRE, K. R. L.; TRAJANO, V. N.; LIMA, I. O.; SOUZA, E. L.; TOLEDO, M. S.; SILVA-FILHO, R. N. Estudo da interferência de óleos essenciais sobre a atividade de alguns antibióticos usados na clínica. Rev. Bras. Farmacog., v. 16, n. 1, p. 77-82, 2006. https://doi.org/10.1590/S0102-695X2006000100014

OSTROSKY, E.A.; MIZUMOTO, M.K.; LIMA, M.E.L.; KANEKO, T.M.; NISHIKAWA, S. O.; FREITAS, B.R. Métodos para avaliação da atividade antimicrobiana de determinação de concentração mínima inibitória (CMI) de plantas medicinais. Rev. Bras. Farmacog., v. 18, n. 2, p. 301-307, 2008. https://doi.org/10.1590/S0102-695X2008000200026

PEREIRA, F. O.; MENDES, J. M.; LIMA, I. O.; MOTA, K. S. L.; OLIVEIRA, W. A.; LIMA, E. O. Antifungal activity of geraniol and citronellol, two monoterpenes alcohols, against Trichophyton rubrum involves inhibition of ergosterol biosynthesis. Pharm. Biol., v. 53, n. 2, p. 1-7, 2014.

PEREIRA CARNEIRO, J. N.; ALBUQUERQUE, R. S.; FIGUEIREDO, L. N.; TARGINO, M. A. J.; VIEIRA DE BRITO, D. I.; ROLÓN, M.; VEJA, C.; CORONEL, C.; COUTINHO, H. D. M.; MORAIS-BRAGA, M. F. B. Avaliação da atividade tripanocida, leishmanicida e citotóxica do geraniol e citronelal. Cad. Cult. Ciênc., v. 13, n. 2, p. 29-36, 2015.

PFALLER, M. A. Antifungal Drug Resistance: Mechanisms, Epidemiology, and Consequences for Treatment. Am. J. Med., v. 125, n. 1, p. 3-13, 2012. https://doi.org/10.1016/j.amjmed.2011.11.001

PICHERSKY, E.; GERSHENZON, J. The formation and function of plant volatiles: perfumes for pollinator attraction and defense. Curr. Opin. Plant. Biol., v. 5, n. 1, p. 237-243, 2002. https://doi.org/10.1016/S13695266(02)00251-0

QUINTANS-JÚNIOR, L.; FAGUNDES DA ROCHA, R.; CAREGNATO, F. F.; MOREIRA, J. C. F.; SILVA, F. A.; ARAÚJO, A. A. S.; ALMEIDA DOS SANTOS, J. P.; MELO, M. S.; SOUSA, D. P.; BONJARDIM, L. R.; GELAIN, D. P. Antinociceptive Action and Redox Properties of Citronellal, an Essential Oil Present in Lemongrass. J. Med. Food. v. 14, n. 6, p. 630-639, 2011. https://doi.org/10.1089/jmf.2010.0125

RATES, S. M. K. Plants as source of drugs. Toxicon. v. 39, n. 5, p. 603-613, 2001. https://doi.org/10.1016/S0041-0101(00)00154-9

RIBEIRO, D. S.; VELOZO, E. S.; GUIMARÃES, A. G. Interaction between the rosemary essential oil (Rosmarinus officinalis L.) and antimicrobial drugs in the control of bacteria isolated from foods. J. Biotechn Biod., v. 4, n. 1, p. 10-19, 2013.

ROLING, E. E.; KLEPSER, M. E.; WASSON, A.; LEWIS, R. E.; ERNST, E. J.; PFALLER, M. A. Antifungal activities of fluconazole, caspofungin (MK0991), and anidulafuingin (LY 303366) alon and in combination against Candida spp. And Cryptococcus neoformans via time-kill methods. Diagn. Micr. Infect. Dis., v. 43, n. 1, p. 13-17, 2002. https://doi.org/10.1016/S0732-8893(02)00361-9

ROSATO, A.; VITALI, C.; GALLO, D.; MILLILLO, M. A.; MALLAMACI, R. The inhibition of Candida species by selected oils and their synergism with amphotericin B. Phytomedicine. v. 15, n. 8, p. 635-638, 2008. https://doi.org/10.1016/j.phymed.2008.05.001

RUIZ-CAMPS, I.; CUENCA-ESTRELLA, M. Antifúngicos para uso sistémico. Enferme infecc. Microbiol. Clin., v. 27, n. 6, p. 353-362, 2009.

SAMY, R. P.; GOPALAKRISHNAKONE, P. Therapeutic potential of plants as antimicrobials for drug discovery. Evid. Based Complement. Alternat. Med., v. 7, n. 3, p. 283-294, 2008. https://doi.org/10.1093/ecam/nen036 
SANCHEZ, M. E.; TURINA, A.; GARCIA, D. A.; VERONICA-NOLAN, M.; PERILLO, M. A. Surface activity of thymol: Implications for an eventual pharmacological activity. Colloids Sur. B Biointerfaces. v. 34, n. 2, p. 77-86, 2004. https://doi.org/10.1016/j.colsurfb.2003.11.007

SCHERER, R.; WAGNER, R.; DUARTE, M. C. T.; GODOY, H. T. Composição e atividade antioxidante e antimicrobiana dos óleos essenciais de cravo-da-Índia, citronela e palmarosa. Rev. Bras. Plantas Med., v. 11, n. 4, p. 442-449, 2009. https://doi.org/10.1590/S1516-05722009000400013

SEKHAVAT, L.; TABATABAII, A.; TEZERJANI, F. Z. Oral fluconazole $150 \mathrm{mg}$ single dose versus intravaginal clotrimazol treatment of acute vulvovaginal candidiasis. J. Infect. Public. Health. v. 4, n. 4, p. 195-199, 2011. https://doi.org/10.1016/j.jiph.2011.05.006

SINGH, B. R.; SINGH, V.; SINGH, R. K.; EBIBENI, N. Antimicrobial activity of lemongrass (Cymbopogon citratus) oil against microbes of environmental, clinical and food origin. Inter. Res. J. Pharm. Pharmacol., v. 1, n. 9, p. 228-236, 2011.

SOBEL, J. D. Management of recurrent vulvovaginal candidiasis with intermitente ketoconazole prophylaxis. Obstet. Gynecol., v. 65, n. 3, p. 435-440, 1985.

SOUSA, E. O.; BARRETO, F. S.; RODRIGUES, F. F. G.; MARTINS DA COSTA, J. G. Atividade antibacteriana e interferência de Lantana camara L. e Lantana montevidensis (Spreng.) Briq. na resistência de aminoglicosídeos. Rev. Bras. Bioci., v. 9, n. 1, p. 1-5, 2011.

SPAMPINATO, C.; LEONARDI, D. Candinda Infections, Causes, Targets, and Resistance Mechanisms: Traditional and Alternativa Antifungal Agents. BioMed Res. International. v. 2013, n. 1, p. 1-13, 2013.https://doi.org/10.1155/2013/204237

https://doi.org/10.1155/2013/923742

TOMAZ, M. A.; VIDAL, C. A.; RODRIGUES, W. N.; PINHEIRO, P. F.; PARREIRA, L. A.; RINALDO, D.; QUEIROZ, V. T. Composição química e atividade alelopática do óleo essencial de eucalipto. Biosci. J., v. 30, n. 2, p. 475-483, 2014.

TROMBETTA, D.; CASTELLI, F.; SARPIETRO, M. G.; VENUTI, V.; CRISTANI, M.; DANIELE, C.; SAIJA, A.; MAZZANTI, G.; BISIGNANO, G. Mechanisms of antibacterial action of three monoterpenes. Antimicrob. Agents Ch., v. 49, n. 6, p. 2474-2478, 2005. https://doi.org/10.1128/AAC.49.6.2474-2478.2005

WAGNER, H.; ULRICH-MERZENICH, G. Synergy research: approaching a new generation of phytopharmaceuticals. Phytomedicine. v. 6, n. 1-3, p. 97-110, 2009.

https://doi.org/10.1016/j.phymed.2008.12.018

WAGNER, H. Multitarget-therapy, the future of treatment for more than just functional dyspepsia. Phytomedicine. v. 13, n. 1, p. 122-129, 2006. https://doi.org/10.1016/j.phymed.2006.03.021

WORKOWSKI, K. A.; BERMAN, S. M. Sexually transmitted diseases treatment guidelines. MMWR Recommend Rep., v. 55, n. 11, p. 1-94, 2006.

ZORE, G. B.; THAKRE, A. D.; JADHAV, S.; KARUPPAYIL, S. M. Terpenoids inhibit Candida albicans growth affecting membrane integrity and arresto of cell cycle. Phytomedicine. v. 18, n. 13, p. 1181-1190, 2011b. https://doi.org/10.1016/j.phymed.2011.03.008

ZORE, G. B.; THAKRE, A. D.; RATHOD, V.; KARUPPAYIL, S. M. Evaluation of anti-Candida potential of geranium oil constituents against clinical isolates of Candida albicans differentially sensitive to fluconazole: inhibition of growth, dimorphism and sensitization. Mycoses. v. 54, n. 4, p. e99-e109, $2011 \mathrm{a}$. https://doi.org/10.1111/j.1439-0507.2009.01852.x 